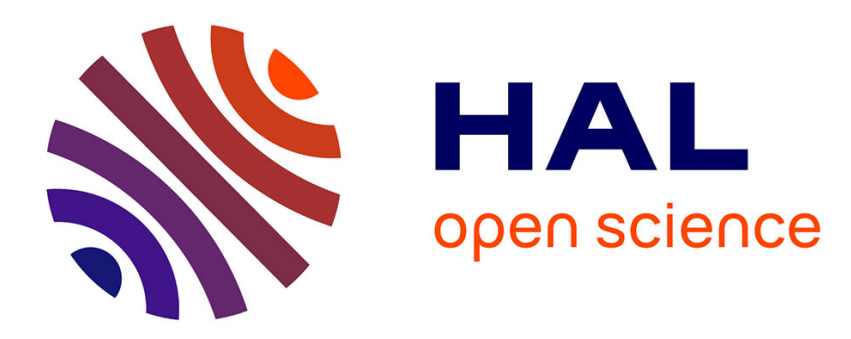

\title{
Frontiers of Serotonin Beyond the Brain
}

\author{
Luc Maroteaux, Fusun Kilic
}

\section{To cite this version:}

Luc Maroteaux, Fusun Kilic. Frontiers of Serotonin Beyond the Brain. Pharmacological Research, 2018, 140, pp.1-6. 10.1016/j.phrs.2018.10.022 . hal-01915456

\section{HAL Id: hal-01915456 https://hal.science/hal-01915456}

Submitted on 7 Nov 2018

HAL is a multi-disciplinary open access archive for the deposit and dissemination of scientific research documents, whether they are published or not. The documents may come from teaching and research institutions in France or abroad, or from public or private research centers.
L'archive ouverte pluridisciplinaire HAL, est destinée au dépôt et à la diffusion de documents scientifiques de niveau recherche, publiés ou non, émanant des établissements d'enseignement et de recherche français ou étrangers, des laboratoires publics ou privés. 


\title{
Frontiers of Serotonin Beyond the Brain
}

\author{
Luc Maroteaux ${ }^{1}$ and Fusun Kilic ${ }^{2}$ *
}

1 UMR-S839 INSERM, Sorbonne Université, Institut du Fer à Moulin, Paris, France ; ${ }^{2}$ Departments of Biochemistry and Molecular Biology, College of Medicine, University of Arkansas for Medical Sciences, Little Rock, Arkansas, USA

*Corresponding author: kilicfusun@uams.edu 
This is the first edition of the Special Issue dedicated to Frontiers of Serotonin; Beyond the Brain to be published in Pharmacological Research. Although serotonin extra-cerebral roles are more and more recognized, this first Keystone Meeting has already provided unbelievable insights into the role of serotonin in peripheral tissues, specifically in gut microbiota, in blood pressure regulation, in bone marrow hematopoiesis, in placenta, in cardiovascular system, in autism spectrum disorders, and in energy homeostasis and placental regulation.

Long time before its identification as 5-hydroxytryptamine (5-HT), the first described effect of serotonin was a cardiovascular action. At the end of 19th century, a substance present in serum, (thrombosed blood fraction), was found to act on heart and blood vessels: in 1896, Weiss showed that intravenous injection of serum into an animal caused an increase in breathing and cardiac frequencies, followed by a rapid decrease in blood pressure leading eventually to death [1]. In 1918, it was reported that citrated serum or blood platelet extract was vasoconstrictor, while uncoagulated blood or citrated plasma did not have a vasoconstrictor action [2]. In 1930, a substance, called enteramine, which contracted smooth muscles was isolated from intestinal enterochromaffin cells [3]. Finally, in late 1940s, a vasoconstrictor substance called serotonin was identified as 5-hydroxytryptamine [4, 5].

Ablation of the peripheral tryptophan hydroxylase 1 (Tph1) gene in mice results in a significant reduction in peripheral, essentially blood $5-\mathrm{HT}$. Nevertheless, there still remains 3 to $15 \%$ of normal concentration originating from a synthesis by neurons of mesenteric plexuses via neuronal subtype of tryptophan hydroxylase gene (Tph2) [6]. Peripheral and non-neuronal 5$\mathrm{HT}$ is released by intestinal neuroendocrine cells to the portal venous system and is then actively uptake by blood platelets within the pulmonary vasculature. In fact, platelets rapidly translocate into lung upon stimulation of 5-HT2 receptors, uptake $5-\mathrm{HT}$ by serotonin transporter (SERT), and then return to circulation. Hence, pulmonary platelet accumulation plays an important role in pulmonary 5-HT removal in mice [7]. In adult organism, 5-HT stored in dense granules of blood platelets is released during activation and/or aggregation phenomena, causing vasoconstrictive effects.

The uptake of $5-\mathrm{HT}$ from the plasma and into platelets occurs rapidly, by a saturable mechanism, which makes platelets the fundamental regulators of plasma 5-HT concentration. Platelet uptake of 5-HT from the plasma is dependent on SERT. After 5-HT is taken in platelet by SERT, it is either sequestered into dense granules by vesicular monoamine transporters (VMAT) [8] or degraded by monoamine oxidase. But prior to sequestration, the 5-HT is capable of activating intracellular signaling pathways linked to platelet activation and aggregation. Notably, plasma 5-HT is in the low nanomolar range, but the dense granules of resting platelets store millimolar concentrations of $5-\mathrm{HT}[9,10]$. Thus, SERT on platelets tightly controls the intracellular/extracellular (plasma) ratio of 5-HT. Clinical and preclinical studies explored the biological role of 5-HT in cardiovascular diseases yet it is incompletely understood.

The plasma $5-\mathrm{HT}$ concentration is elevated in cardiovascular disorders [11] including hypertension [12], coronary artery disease [13-15], thrombosis [16, 17] and myocardial infarction [18]. For example, in an earlier study, we reported a $33 \%$ increase in plasma $5-\mathrm{HT}$ concentration of the patients diagnosed with white-coat hypertension after an episodic incident [16]. Vikenes et al. noted a 10-fold elevation of plasma 5-HT concentration during angiography of the patients with myocardial infarction. In these patients, the elevated plasma 5-HT was associated with coronary artery disease and cardiac events [14]. Thus, a physiological in vivo interplay between circulating $5-\mathrm{HT}$ and platelet function may be a ratio and myocardial infarction have been linked to elevated plasma 5-HT concentrations [18]. Indeed, TPH1 
knockout (KO) mice lacking 5-HT have a mild bleeding abnormality [19]. Notably, the deficit of anti-coagulant molecules may permit amplification of the opposing, pro-coagulant actions of 5-HT [17].

In periphery, 5-HT also contributes to hematopoiesis, immune regulation, embryonic development, placenta functions and gut to brain relationships. It may be surprising that a unique mediator possesses so many different functions. This diversity can be explained by the fact that 5-HT acts through numerous receptors. Gaddum and Picarelli [20], working on guinea pig ileum, proposed that 5-HT acts, on two pharmacologically different receptors, M (muscarinsensitive) and D (dibenzylin-sensitive) receptors located on smooth muscles and neurons respectively. During early $90 \mathrm{~s}$, identification of $5-\mathrm{HT}$ receptor genes has progressed considerably with gene cloning and sequencing techniques. Except $5-\mathrm{HT}_{3}$ receptors, which are 5-HT-gated ion channels, all others are G-protein coupled receptors (GPCRs). 5-HT receptors have the highly-conserved structure of seven transmembrane domains common to all GPCRS, including three extracellular loops involved in ligand recognition and three intracellular loops involved in intracellular signaling mainly through G-protein-mediated pathways. It now appears that there are 15 different receptor genes, divided into four subtypes: $5-\mathrm{HT}_{1 / 5}, 5-\mathrm{HT}_{2}, 5-\mathrm{HT}_{3}$, and 5- $\mathrm{HT}_{4 / 6 / 7}$ [21]. These receptors are grouped according to their intracellular coupling mode: Gi proteins for $5-\mathrm{HT}_{1 / 5}, \mathrm{Gs}$ for $5-\mathrm{HT}_{4 / 6 / 7}$ and finally $\mathrm{Gq}$ for $5-\mathrm{HT}_{2}$.

Starting from the observation that the Htr2b gene, coding for the $5-\mathrm{HT}_{2 \mathrm{~B}}$ receptor is encoded within an intron of a large subunit of the proteasome Psmd1, in humans, mice and rats, Moutkine et al., summarizes existing data from genome sequencing supporting that association between these two genes appeared in pre-vertebrates [22]. Earlier work indicated that $5-\mathrm{HT}$ and $5-\mathrm{HT}_{2 \mathrm{~B}}$ receptors regulate many functions acquired during early differentiation of vertebrates, including neural crest cells, heart, and bone marrow stem cells differentiation and proliferation. In addition, these data revealed that during genome duplications, a strong selective pressure seems to keep a single copy of this genetic association to the proteasome Psmd1 gene. Together with its early appearance in pre-vertebrates and its persistence throughout evolution, this association may have functional consequences, and raised the possibility that the $5-\mathrm{HT}_{2 \mathrm{~B}}$ receptor is the common ancestor of the $5-\mathrm{HT}_{2 \mathrm{~A} / 2 \mathrm{~B} / 2 \mathrm{C}-\text { receptor }}$ subfamily [22].

Outside the central nervous system, 5-HT can be synthesized in gastrointestinal tract and enteric nerves, but also in hematopoietic stem cells, and some immune cells, in which 5-HT regulates inflammation and immunity by acting on 5-HT receptors that are differentially expressed on immune cells, both in rodents and humans.

\section{5-HT and hematopoiesis}

Previous studies have shown that $5-\mathrm{HT}$ is a growth factor for hematopoietic stem/progenitor cells. A $5-\mathrm{HT}_{2 B}$ receptor expression was identified in megakaryocytic cell lineage; $5-\mathrm{HT}$ promoted the megakaryocytes proliferation, reduced apoptosis via the activation of the Akt pathway [23], and polymerized actin via ERK1/2 [24]. Mice deficient in peripheral 5-HT synthetizing enzyme, $\mathrm{Tph}^{-/}$mice, displayed morphological and cellular features of ineffective erythropoiesis; in the bone marrow, the absence of 5- $\mathrm{HT}$ limited the differentiation of erythroid precursors expressing $5-\mathrm{HT}_{2 \mathrm{~A}}$ and $5-\mathrm{HT}_{2 \mathrm{~B}}$ receptors [25]. In $T p h 2^{-/-}$-deficient embryos, a decrease in 5-HT synthesized in the aorta-gonad-mesonephros leads to apoptosis of nascent hematopoietic stem cells; 5-HT inhibits the Akt-Foxo1 signaling cascade and protects hematopoietic stem cells from excessive apoptosis [26]. Furthermore, 5-HT significantly enhanced the amount of early stem/progenitors and multilineage committed progenitors (burstforming unit/colony-forming unit-erythroid, colony-forming unit-granulocyte macrophage, and colony-forming unit-megakaryocyte lineages) [27] during adult hematopoiesis. Independently, 
the 5- $\mathrm{HT}_{2 \mathrm{~B}}$ receptor expression was detected in precursors c-kit ${ }^{+}$bone-marrow cells; the 5$\mathrm{HT}_{2 \mathrm{~B}}$ receptor selective antagonist RS127445 decreased colony-forming capacity with inhibition of myeloid lineage formation, endothelial precursor cells differentiation, and monocyte/macrophage release [28].

Albeit within an organ or a specific cell type, local TPH enzymatic activity, followed by endogenous production of 5-HT and the presence of serotonergic components (receptors, SERT) are of importance and support the view that $5-\mathrm{HT}$ is a monoamine with a paracrine/autocrine function. Hence, a locally derived source of 5-HT acting directly on 5-HT receptors present on hematopoietic stem cells does not require an intermediate signal. One concern can be how to specifically increase 5-HT concentration locally, for instance in the bone marrow for the development of hematopoietic stem cells. Available molecules include 5-HT receptors specific agonists and antagonists, or SSRI, however whether these drugs could increase extracellular concentrations and signaling of 5- $\mathrm{HT}$ in the bone marrow remains unknown. Timing is also an important concern as it seems that $5-\mathrm{HT}$ is critical at specific checkpoints, or after an injury. Altogether, the serotonergic system may be a promising therapeutic target with broad regenerative capacity to regulate stem cell maintenance and regeneration following various types of injury [29].

\section{5-HT and immune system}

The defense against pathogens is mediated by innate and adaptive immune mechanisms. 5$\mathrm{HT}$ regulates inflammation and immunity by acting on $5-\mathrm{HT}$ receptors that are differentially expressed on immune cells, both in rodents and humans. 5-HT acts as a potent chemoattractant, recruiting innate immune cells to sites of inflammation. 5-HT also alters the production and release of cytokines and cell activation/proliferation. Some immune cells, including mast cells and T-lymphocytes, have the capacity to synthesize and release $5-\mathrm{HT}$, expanding the range of tissues for 5-HT signaling. There is a growing body of evidence suggesting that many different types of immune cells express the machinery to generate, store, respond to and/or transport $5-\mathrm{HT}$, including $\mathrm{T}$ cells, macrophages, mast cells, dendritic cells and platelets.

Monocytes are the largest type of leukocyte and can differentiate into macrophages and myeloid lineage dendritic cells. In human monocytes (CD14+), mRNA expression of 5-HT $\mathrm{HE}_{1 \mathrm{E}}$ $5-\mathrm{HT}_{2 \mathrm{~A}}, 5-\mathrm{HT}_{3}, 5-\mathrm{HT}_{4}$ and $5-\mathrm{HT}_{7}$ receptors is detectable [30]. In mature human macrophages, 5-HT can inhibit LPS (lipopolysaccharide of the bacterial wall that mimics bacterial infection via toll-like receptor -TLR4 on immune cells)-induced release of proinflammatory cytokines, upregulate the expression of M2 polarization-associated genes, and reduce the expression of M1-associated genes. 5-HT instructs macrophages, reduces IFN type I-mediated signaling, and promotes an anti-inflammatory signature. In fact, blockade of $5-\mathrm{HT}_{2 \mathrm{~B}}$ receptors during invitro monocyte-to-macrophage differentiation preferentially modulated the acquisition of M2 polarization markers. Htr $2 B$ mRNA was found to be preferentially expressed by antiinflammatory M2 (M-CSF) macrophages and was detected in-vivo in liver Kupffer cells and in tumor-associated macrophages [31]. The acquisition of this gene profile and upregulation of TGF $\beta 1$ production depend also on the $5-\mathrm{HT}_{7}$ receptor and PKA-signaling [32]. Dendritic cells are potent antigen-presenting cells endowed with the unique ability to initiate adaptive immune responses upon inflammation. Immature dendritic cells preferentially express mRNA for 5$\mathrm{HT}_{1 \mathrm{~B}}, 5-\mathrm{HT}_{1 \mathrm{E}}$ and $5-\mathrm{HT}_{2 \mathrm{~A} / 2 \mathrm{~B}}$ receptors [33]. Expression for 5- $\mathrm{HT}_{1 \mathrm{~B}}, 5-\mathrm{HT}_{1 \mathrm{~F}}, 5-\mathrm{HT}_{2 \mathrm{~A}}, 5-\mathrm{HT}_{2 \mathrm{~B}}, 5-$ $\mathrm{HT}_{6}$, and $5-\mathrm{HT}_{7}$ receptor mRNAs was also detected in spleen, thymus, and peripheral blood lymphocytes [34]. In human umbilical cord blood, $T$ helper cells differentiation was found to specifically express $5-\mathrm{HT}_{2 \mathrm{~B}}$ receptors among Th2 differentially expressed genes [35]. In addition, during human $\mathrm{CD} 41 \mathrm{~T}$ cell differentiation, $5-\mathrm{HT}_{2 \mathrm{~B}}$ receptors were found to be SP4specific [36]. 
The role of many of the 5-HT receptors expressed by immune cells is still only partially elucidated. An understanding of the role of $5-\mathrm{HT}$ in T cells is of particular interest, as T cells play a critical role to direct the immune response and the extent of inflammation. The $T$ cells can differentiate and specialize once activated in vivo and 5-HT may play a differential role depending on the subtype, particularly in effector T cell populations (Th1, Th17, CD8) and regulatory $T$ cells (Treg). The presence of different receptor subtypes on a single immune cell, for example, raises the question of what the specific function of each receptor subtype might be. Overall, the influence of 5-HT on the peripheral immune system remains an open question. Furthermore, there is emerging evidence of a possible connection between T cells, 5-HT and mood disorders. Multiple studies suggest that patients with major depressive disorders have an elevated Th17:Treg ratio, with reduced numbers and percentages of Treg compared to healthy controls. How 5-HT interacts with the peripheral immune system and if this signaling is associated with behavioral phenotypes found in mood disorders like major depressive disorder is not well understood. Current evidence that peripheral immune system alterations and CNS function may be interrelated and the possible implications of these findings for drug discovery [37].

\section{Cardiovascular functions of 5-HT}

In periphery, 5-HT contributes to control many cardiovascular functions: in addition to effects on platelet aggregation and hematopoietic stem cells differentiation, 5-HT can modulate blood pressure, heart rate and respiration. Cardiac functions of animals born from Tph1-/- mice are strongly affected with contractile abnormalities thus demonstrating critical functions of maternal 5-HT on embryonic development [38]. The acute cardiovascular response to 5-HT, named the Bezold-Jarish reflex, leads to intense bradycardia associated with atrioventricular block, and involves 5- $\mathrm{HT}_{3}, 5-\mathrm{HT}_{1 \mathrm{~B}}, 5-\mathrm{HT}_{7}$ and 5- $\mathrm{HT}_{2 \mathrm{~A} / 2 \mathrm{~B}}$ receptors. 5- $\mathrm{HT}$ and its receptors (5$\mathrm{HT}_{4}$ and $5-\mathrm{HT}_{2 \mathrm{~A} / 2 \mathrm{~B}}$ ) participates in cardiac development [39], and in cardiovascular tissue remodeling [40]. In particular, 5-HT regulates cardiac hypertrophy and fibrosis [40]. The cardiovascular functions of $5-\mathrm{HT}$, often unrecognized, have recently been re-evaluated in particular in cerebral and pulmonary circulatory beds with development of "serotonergic" drugs for treatment of migraines and likely in a near future in primary pulmonary arterial hypertension. $5-\mathrm{HT}$, its transporter, $5-\mathrm{HT}_{1 \mathrm{~B}}$, and $5-\mathrm{HT}_{2 \mathrm{~B}}$ receptors participate in pulmonary hypertension and pulmonary vascular remodeling $[41,42]$. Bone marrow derived endothelial progenitors contribute to the pathogenesis of pulmonary hypertension [28] and involve bone morphogenetic protein type 2 receptor signaling.

5-HT participates in heart valve diseases. Some valve degenerative processes such as the carcinoid heart disease, drug-induced valvulopathy and degenerative mitral valve disease in inbreed dogs are clearly linked to $5-\mathrm{HT}$. Fenfluramine or ergot derivatives were linked to mitral and aortic valve dysfunction and share in common the pharmacological property of being 5$\mathrm{HT}_{2 \mathrm{~B}}$ receptor agonists. This heart valve degeneration has been linked to high serum serotonin, $5-\mathrm{HT}_{2 \mathrm{~B}}$ receptor overexpression and SERT downregulation. Using mice models and bonemarrow transplantation experiments, early heart valve degeneration was shown to involve the mobilization of endothelial progenitor cells after $5-\mathrm{HT}_{2 \mathrm{~B}}$ receptor stimulation. The identification of endothelial progenitors sharing this receptor in human mitral valve prolapse tissues reveals the relevance of this mechanism in human heart valve remodelling [43]. Many other proposed molecular mechanisms for heart valve degeneration are also probabaly implicated and involve (i) a 5-HT-mediated activation of G-protein receptor signal transduction that results in a local mitogenic effect; (ii) the 5-HT-induced TGF- $\beta 1$ expression regulates the remodeling of the extracellular matrix via endothelial to mesenchymal transition; (iii) finally, serotonylation and intracellular interaction with cytoskeletal components, such as Rac1 [44], Rab4 [45] and Filamin-A [46]. 
The participation of $5-\mathrm{HT}_{1 \mathrm{~B}}, 5-\mathrm{HT}_{7}$ and $5-\mathrm{HT}_{2 \mathrm{~A} / 2 \mathrm{~B}}$ receptors in vasomotor tone regulation and the interaction between endothelial and smooth muscle cells are also be discussed. In arterial wall, endothelial cells express $5-\mathrm{HT}_{1 \mathrm{~B}}, 5-\mathrm{HT}_{2 \mathrm{~B}}$ and $5-\mathrm{HT}_{4}$ receptors, whereas smooth muscle cells express $5-\mathrm{HT}_{1 \mathrm{~B}}, 5-\mathrm{HT}_{2 \mathrm{~A}}, 5-\mathrm{HT}_{7}$ receptors and in some cases $5-\mathrm{HT}_{2 \mathrm{~B}}$. This expression pattern suggests that $5-\mathrm{HT}$ plays a complex role in regulating vasomotor tone [47]. Indeed, receptors expressed on endothelial cells can induce vasodilation while stimulation by $5-\mathrm{HT}$ of smooth muscle cells elicits vasoconstriction. The contribution of serotonergic receptors in blood pressure regulation is well studied [48]. $5-\mathrm{HT}_{2 \mathrm{~A}}$ receptors are mainly responsible for contraction of large arteries as opposed to veins that contract following $5-\mathrm{HT}_{1 \mathrm{~B}}$-receptor stimulation [49]. By contrast, not all blood vessels can relax to 5-HT; in jugular vein and pulmonary artery and coronary arteries, $5-\mathrm{HT}$ causes relaxation through activation of $5-\mathrm{HT}_{2 \mathrm{~B}}$ and $5-\mathrm{HT}_{7}$ receptors [48]. Recent work confirmed that the superior mesenteric vein possesses a highly sensitive $5-\mathrm{HT}_{7}$ receptor that mediates venous relaxation without requiring blockade of contractile receptors, not excluding the potential involvement of the 5- $\mathrm{HT}_{2 B}$ receptor [50]. Furthermore, perivascular adipose tissue (PVAT) modulates vascular tone and altered PVAT function is observed in vascular diseases such as hypertension and atherosclerosis. The PVAT surrounding rat thoracic aorta and the superior mesenteric artery contain significant amounts of 5-HT. interestingly, fenfluramine, a compound believed to react preferentially with serotonergic system, primarily stimulates norepinephrine release (better than 5-HT) in a norepinephrine transporter-dependent manner, leading to vasoconstriction. This adds additional support to PVAT as being an important reservoir of amines [51].

\section{The gut, 5-HT, immune to brain relationships}

Remarkably, the absence of microbiome in germ-free mice impacts both prenatal and postnatal microglia. Antibiotic treatment of adult mice can also trigger modified microglial responses revealing both acute and long-term effects of microbiota depletion [52]. The enteric nervous system interacts tightly with the immune system in order to protect the organism from ingested environmental pathogens. 5-HT-producing cells in the gut (enterochromaffin cells) are synthetizing most of the 5-HT produced in periphery via TPH1 enzyme. Cross-talks between the enteric nervous and immune systems maintain homeostatic regulation of the gut activity. In response to microbial stimuli, neuroendocrine cells can release 5-HT, whereas activated immune cells including mucosal macrophages and mast cells can release various cytokines, see for review [53]. The innate immune system is, thus, crucial in the gastrointestinal tract, being the first line of defense against pathogens. The immune system can detect and recognize microbial-associated molecular patterns through pattern recognition receptors such as TLRs and nucleotide oligomerization domain (NOD)-like receptors that trigger different responses to maintain intestinal homeostasis. Recent work showed that NOD1 activation inhibits SERT activity and expression in intestinal epithelial cells, and can be regulated by TLR2 and TLR4 activation [54]. This study gave the first molecular partners involved in putative relation between intestinal serotonergic and innate immune system, and their implications in inflammation.

Pioneering work by Clarke et al., [55] showed that germ-free animals have a significant increase in 5-HT concentration in the hippocampus that cannot be reversed in post weaning animals by microbiota colonization. The CNS serotonergic neurotransmission can thus be profoundly modified by the gut microbiota. Various diets have also been shown to regulate the expression of many genes in the brain; changes in gene expression related to neuroplasticity including 5- $\mathrm{HT}_{1 \mathrm{~A}}$ receptors are associated to place memory in the hippocampus, and particular microbiota; object memory performance is correlated with perirhinal $5-\mathrm{HT}_{2 \mathrm{C}}$-receptor expression and other type of microbiota [56]. Furthermore, modifying microbiota can be beneficial in some pathological situations with memory deficits but not in healthy subjects. Gut microbiota can communicate with the brain through several different mechanisms. This includes production of immune factors (e.g. cytokines), innervation via the vagus nerve, or 
activation of the HPA axis. Reciprocally input from the CNS can regulate enteric physiology [53].

Autism-spectrum disorder (ASD) is a neurodevelopmental disorder characterized by persistent deficits in social communication and repetitive patterns of behavior. A variety of human and animal studies support the hypothesis that $5-\mathrm{HT}$ system dysfunction is a contributing factor to the development of autism in some patients. During pregnancy, fetal 5-HT synthesis requires TRP from maternal circulation throughout gestation. Early in gestation, TPH1 converts tryptophan (TRP) to 5-HT in the placenta, whereas late in gestation, TPH2 converts TRP to 5HT in fetal hindbrain. Thus, numerous factors that influence this pathway have the potential, both alone and in combination, to influence 5-HT system function and development. For example, pharmacologic inactivation (e.g., SSRI) and/or genetic (functional polymorphisms) modulation of SERT function, within the mother, fetus, or both, can have cascading effects on TRP demand and 5-HT signaling capabilities. These disruptions, during the critical neurodevelopmental period, can cause permanent deficits in serotonergic system tone. Because 5-HT serves as a neurotrophic factor during brain development, such perturbations can also profoundly affect non-serotonergic neurons and pathways. As a result, excessive or insufficient $5-\mathrm{HT}$ tone can facilitate neurophysiological and behavioral outcomes relevant to autism, such as social behavior deficits and repetitive stereotypies [57]. A deeper understanding of the many mechanisms by which $5-\mathrm{HT}$ signaling can be disrupted, alone and in concert, may contribute to an improved understanding of the etiologies and heterogeneous nature of this disorder.

ASD is often associated with medical comorbidities and gastrointestinal (GI) dysfunction is among the most common. Studies have demonstrated a correlation between $\mathrm{Gl}$ dysfunction and the degree of social impairment in ASD. After being synthesized in the intestinal epithelium by TPH1 enzyme expressed by enterochromaffin (EC) cells, luminal distention of the gut results in the basal release of $5-\mathrm{HT}$ into the interstitial space of the lamina propria, leading to local activation of 5-HT receptors on intrinsic primary afferent neurons in both the submucosal and myenteric plexuses. 5-HT is inactivated through the actions of the SERT, which is expressed by intestinal epithelial cells. Once intracellular, 5-HT is stored back in secretory vesicles or degraded by monoamine oxidase (MAO) into 5-hydroxyindoleacetic acid (5-HIAA). The enteric nervous system contains 5-HT-synthesizing neurons. Enteric neurons utilize TPH2, to synthesize 5-HT, which is then stored in synaptic vesicles. Secreted 5-HT activates postsynaptic receptors and is then inactivated through pre-synaptic reuptake by SERT, where it can be packaged into vesicles once again for release or degraded by MAO into 5-HIAA. The gut phenotype in the SERT Ala56 mice can be rescued by pharmacological modulation of the 5 -HT4 receptor. Although microbiome studies thus far demonstrate a bidirectional relationship between 5-HT and the enteric microbiota, the precise nature of the in vivo mechanisms governing this relationship have yet to be determined [58]. As a critical modulator of enteric and central nervous system development and function, 5-HT may be a nexus for the gut-brain axis in ASD.

\section{Placenta and diabetes}

Trophoblast cells express many components of the 5-HT system such as SERT [59-61], receptors, 5-HT1A and 5-HT2A [60, 62] and monoamine oxidase, MAO [63] which catabolizes $5-\mathrm{HT}$. On the plasma membrane of the trophoblast cells, SERT regulates extracellular $5-\mathrm{HT}$ levels and prevents the vasoconstriction of placental vascular bed and thereby secures a stable blood flow to the embryo. In different tissues, 5-HT promotes cell division and mitosis and lead acts as a developmental signal early in embryogenesis [38] but continuous 5-HT signaling is involved in cell death mechanisms via activation of phosphatidylinositol-3 kinase (PI3K)/AKT and extracellular signal-regulated kinase (ERK) 1/2 signaling pathways $[64,65]$. 
SERT has an important role which is supported by many clinical studies (but not all) report increased rates of congenital prematurity and malformations, including defects in fetal forebrain development, induced by SSRI during pregnancy [66-68]. Reducing 5-HT uptake rates of SERT by SSRI alters the plasma vs platelet 5-HT ratio; as reported using SSRI in the first trimester had approximately a 2-fold increased risk for cardiac and a 1.8-fold increased risk for other congenital malformations compared to the entire national registry population (http://www.ncbi.nlm.nih.gov/pubmed/22052679) [69]. Furthermore, studies with preclinical models report that mice lacking the gene for SERT (SERT-KO) $[59,70]$ or the gene for TPH1 (TPH1-KO) [19, 38, 71] exhibit insulin resistance and glucose intolerance, and progressively develop obesity and hepatic steatosis [72]. These studies clearly throw additional role to 5-HT and emphasize the importance of SERT in trophoblast more than functioning as a transporter, protecting the trophoblast cells against continuous $5-\mathrm{HT}$ signaling. The findings from TUNEL and proliferation assays demonstrated that the cells death rates in SERT-KO placentas were several-fold elevated at the maternal side as compared to the placentas of TPH1-KO and WT mice. Further analysis of the placentas from SERT-KO mice for Caspase3 staining suggested that the placental damage in the absence of SERT, at elevated 5-HT signaling, occurs in caspase3-independent pathway [59].

Molecular cloning of SERT cDNA from human and rat brain in the 1980s [73-75] opened a new era in our understanding of the structure, function and important regulatory features of SERT. SERT is an oligomeric $N$-glycan $[76,77]$ and contains disulfide bonds between cysteine residues $[78,79]$ on the second extracellular domains. Post-translational modifications regulate the uptake kinetics and membrane trafficking of SERT, in part by regulating the proper folding and assembly of SERT in a host-dependent manner [80]. As a result, these modifications have important effects on $5-\mathrm{HT}$ roles in the central nervous system and in the periphery $[44,59,81,82]$. Thus, identification of the pathways and factors associated with post-translational modification of SERT is important to understand SERT function in various biological processes. 


\section{REFERENCES}

[1] O. Weiss, Über die Wirkungen von Blutserum-Injectionen ins Blut, Archiv für die Gesamte Physiologie des Menschen und der Thiere LXV (1896) 215-230.

[2] T.C. Janeway, H.B. Richadson, E.A. Park, Experiments on the vasoconstrictor action of blood serum, Arch. Int. Med. 21 (1918) 565-603.

[3] M. Vialli, V. Erspamer, Xellule enterochromaffini e cellule basigranulose acidofile nei vertebrati, Z. Zellforsch. Mikrosk. Anat. 19 (1933) 743.

[4] M.M. Rapport, A.A. Green, I.H. Page, Serum vasoconstrictor, serotonin; isolation and characterization, J Biol Chem 176(3) (1948) 1243-51.

[5] M.M. Rapport, A.A. Green, I.H. Page, Crystalline Serotonin, Science 108(2804) (1948) 329330.

[6] F. Côté, E. Thevenot, C. Fligny, Y. Fromes, M. Darmon, M.A. Ripoche, E. Bayard, N. Hanoun, F. Saurini, P. Lechat, L. Dandolo, M. Hamon, J. Mallet, G. Vodjdani, Disruption of the nonneuronal tph1 gene demonstrates the importance of peripheral serotonin in cardiac function, Proc Natl Acad Sci USA 100(23) (2003) 13525-30.

[7] Z. Yu, M. Ohba, M. Nakamura, T. Sasano, M. Ono, S. Sugawara, Y. Endo, Dynamics of platelet mobilisation into lungs in response to 5-hydroxytryptamine (serotonin) in mice, Thromb Haemost 102(6) (2009) 1251-8.

[8] I. Brunk, C. Blex, S. Rachakonda, M. Holtje, S. Winter, I. Pahner, D.J. Walther, G. AhnertHilger, The first luminal domain of vesicular monoamine transporters mediates G-proteindependent regulation of transmitter uptake, J Biol Chem 281(44) (2006) 33373-85.

[9] H. Holmsen, H.J. Weiss, Secretable storage pools in platelets, Annu Rev Med 30 (1979) 119-34.

[10] A. McNicol, S.J. Israels, Platelets and anti-platelet therapy, J Pharmacol Sci 93(4) (2003) 381-96.

[11] P.R. Saxena, C.M. Villalón, Cardiovascular effects of serotonin agonists and antagonists, J Cardiovasc Pharmacol 15(Suppl 7) (1990) S17-34.

[12] P. Singh, T.W. Fletcher, Y. Li, N.J. Rusch, F. Kilic, Serotonin uptake rates in platelets from angiotensin II-induced hypertensive mice, Health (Irvine Calif) 5(4A) (2013) 31-39.

[13] D. Leosco, M. Fineschi, C. Pierli, A. Fiaschi, N. Ferrara, S. Bianco, G. Longobardi, E. Pisani, A. Bravi, F. Rengo, Intracoronary serotonin release after high-pressure coronary stenting, Am J Cardiol 84(11) (1999) 1317-22.

[14] K. Vikenes, M. Farstad, J.E. Nordrehaug, Serotonin is associated with coronary artery disease and cardiac events, Circulation 100(5) (1999) 483-9.

[15] E.K. van den Berg, J.M. Schmitz, C.R. Benedict, C.R. Malloy, J.T. Willerson, G.J. Dehmer, Transcardiac serotonin concentration is increased in selected patients with limiting angina and complex coronary lesion morphology, Circulation 79(1) (1989) 116-24.

[16] B. Brenner, J.T. Harney, B.A. Ahmed, B.C. Jeffus, R. Unal, J.L. Mehta, F. Kilic, Plasma serotonin levels and the platelet serotonin transporter, J Neurochem 102(1) (2007) 20615.

[17] E. Ziu, C.P. Mercado, Y. Li, P. Singh, B.A. Ahmed, S. Freyaldenhoven, S. Lensing, J. Ware, F. Kilic, Down-regulation of the serotonin transporter in hyperreactive platelets counteracts the pro-thrombotic effect of serotonin, J Mol Cell Cardiol 52(5) (2012) 111221.

[18] S. Yamada, H. Akita, K. Kanazawa, T. Ishida, K. Hirata, K. Ito, S. Kawashima, M. Yokoyama, T102C polymorphism of the serotonin (5-HT) 2A receptor gene in patients with non-fatal acute myocardial infarction, Atherosclerosis 150(1) (2000) 143-8.

[19] D.J. Walther, J.U. Peter, S. Winter, M. Holtje, N. Paulmann, M. Grohmann, J. Vowinckel, V. Alamo-Bethencourt, C.S. Wilhelm, G. Ahnert-Hilger, M. Bader, Serotonylation of small GTPases is a signal transduction pathway that triggers platelet alpha-granule release, Cell 115(7) (2003) 851-62.

[20] J.H. Gaddum, Z.P. Picarelli, Two kinds of tryptamine receptors, Br J Pharmacol 12 (1957) 323-328. 
[21] S.P.H. Alexander, H.E. Benson, E. Faccenda, A.J. Pawson, J.L. Sharman, M. Spedding, J.A. Peters, A.J. Harmar, C. Collaborators, The Concise Guide to PHARMACOLOGY 2013/14: G protein-coupled receptors, Br J Pharmacol 170(8) (2013) 1459-581.

[22] I. Moutkine, E.L. Collins, C. Béchade, L. Maroteaux, Evolutionary considerations on 5HT2 receptors, Pharmacological Research (2018).

[23] Y.S. Liu, M. Yang, The effect of 5-hydroxtryptamine on the regulation of megakaryocytopoiesis, Hematology 11(1) (2006) 53-6.

[24] J.Y. Ye, E.Y. Liang, Y.S. Cheng, G.C.F. Chan, Y. Ding, F. Meng, M.H.L. Ng, B.H. Chong, Q. Lian, M. Yang, Serotonin Enhances Megakaryopoiesis and Proplatelet Formation via p-Erk1/2 and F-Actin Reorganization, Stem Cells 32(11) (2014) 2973-82.

[25] P. Amireault, S. Hatia, E. Bayard, F. Bernex, C. Collet, J. Callebert, J.-M. Launay, O. Hermine, E. Schneider, J. Mallet, M. Dy, F. Côté, Ineffective erythropoiesis with reduced red blood cell survival in serotonin-deficient mice, Proc Natl Acad Sci USA 108(32) (2011) 13141-6.

[26] J. Lv, L. Wang, Y. Gao, Y.-Q. Ding, F. Liu, 5-hydroxytryptamine synthesized in the aortagonad-mesonephros regulates hematopoietic stem and progenitor cell survival, J Exp Med 214(2) (2017) 529-545.

[27] M. Yang, K. Li, P.C. Ng, C.K. Chuen, T.K. Lau, Y.S. Cheng, Y.S. Liu, C.K. Li, P.M. Yuen, A.E. James, S.M. Lee, T.F. Fok, Promoting effects of serotonin on hematopoiesis: ex vivo expansion of cord blood CD34+ stem/progenitor cells, proliferation of bone marrow stromal cells, and antiapoptosis, Stem Cells 25(7) (2007) 1800-6.

[28] J.-M. Launay, P. Hervé, J. Callebert, Z. Mallat, C. Collet, S. Doly, A. Belmer, S.L. Diaz, S. Hatia, F. Côté, M. Humbert, L. Maroteaux, Serotonin 5-HT2B receptors are required for bone-marrow contribution to pulmonary arterial hypertension, Blood 119(7) (2012) 17721780.

[29] G. Fouquet, T. Coman, O. Hermine, F. Côté, Serotonin, hematopoiesis and stem cells, Pharmacological Research (2018).

[30] T. Dürk, E. Panther, T. Müller, S. Sorichter, D. Ferrari, C. Pizzirani, F. Di Virgilio, D. Myrtek, J. Norgauer, M. Idzko, 5-Hydroxytryptamine modulates cytokine and chemokine production in LPS-primed human monocytes via stimulation of different 5-HTR subtypes, Int Immunol 17(5) (2005) 599-606.

[31] M. de Las Casas-Engel, A. Domínguez-Soto, E. Sierra-Filardi, R. Bragado, C. Nieto, A. Puig-Kroger, R. Samaniego, M. Loza, M.T. Corcuera, F. Gómez-Aguado, M. Bustos, P. Sánchez-Mateos, A.L. Corbí, Serotonin skews human macrophage polarization through HTR2B and HTR7, J Immunol 190(5) (2013) 2301-10.

[32] Á. Domínguez-Soto, A. Usategui, M.d.I. Casas-Engel, M. Simón-Fuentes, C. Nieto, V.D. Cuevas, M.A. Vega, J. Luis Pablos, Á.L. Corbí, Serotonin drives the acquisition of a profibrotic and anti-inflammatory gene profile through the 5-HT7R-PKA signaling axis, Scientific Reports 7(1) (2017) 14761.

[33] M. Idzko, E. Panther, C. Stratz, T. Müller, H. Bayer, G. Zissel, T. Dürk, S. Sorichter, F. Di Virgilio, M. Geissler, B. Fiebich, Y. Herouy, P. Elsner, J. Norgauer, D. Ferrari, The serotoninergic receptors of human dendritic cells: identification and coupling to cytokine release, J Immunol 172(10) (2004) 6011-9.

[34] J. Stefulj, B. Jernej, L. Cicin-Sain, I. Rinner, K. Schauenstein, mRNA expression of serotonin receptors in cells of the immune tissues of the rat, Brain Behav Immun 14(3) (2000) 219-24.

[35] T. Aijö, S.M. Edelman, T. Lönnberg, A. Larjo, H. Kallionpää, S. Tuomela, E. Engström, R. Lahesmaa, H. Lähdesmäki, An integrative computational systems biology approach identifies differentially regulated dynamic transcriptome signatures which drive the initiation of human T helper cell differentiation, BMC Genomics 13 (2012) 572.

[36] M.S. Lee, K. Hanspers, C.S. Barker, A.P. Korn, J.M. McCune, Gene expression profiles during human CD4+ T cell differentiation, Int Immunol 16(8) (2004) 1109-24.

[37] H. Wu, T.H. Denna, J.N. Storkersen, V.A. Gerriets, Beyond a neurotransmitter: The role of serotonin in inflammation and immunity, Pharmacological Research (2018). 
[38] F. Cote, C. Fligny, E. Bayard, J.M. Launay, M.D. Gershon, J. Mallet, G. Vodjdani, Maternal serotonin is crucial for murine embryonic development, Proc Natl Acad Sci USA 104(1) (2007) 329-34.

[39] D.-S. Choi, S. Ward, N. Messaddeq, J.-M. Launay, L. Maroteaux, 5-HT2B receptormediated serotonin morphogenetic functions in mouse cranial neural crest and myocardiac cells, Development 124 (1997) 1745-1755.

[40] C.G. Nebigil, D.-S. Choi, A. Dierich, P. Hickel, M. Le Meur, N. Messaddeq, J.-M. Launay, L. Maroteaux, Serotonin 2B receptor is required for heart development, Proc Natl Acad Sci USA 97 (2000) 9508-9513.

[41] M.R. MacLean, Y. Dempsie, Serotonin and pulmonary hypertension--from bench to bedside?, Curr Opin Pharmacol 9(3) (2009) 281-6.

[42] J.M. Launay, P. Hervé, K. Peoc'h, C. Tournois, J. Callebert, C. Nebigil, N. Etienne, L. Drouet, M. Humbert, G. Simonneau, L. Maroteaux, Function of the serotonin 5hydroxytryptamine 2B receptor in pulmonary hypertension, Nat Med 8 (2002) 1129-1135.

[43] E. Ayme-Dietrich, R. Lawson, F. Côté, C. de Tapia, S. Da Silva, C. Ebel, B. Hechler, C. Gachet, J. Guyonnet, H. Rouillard, J. Stoltz, E. Quentin, S. Banas, F. Daubeuf, N. Frossard, B. Gasser, J. Mazzucotelli, O. Hermine, L. Maroteaux, L. Monassier, Serotonergic 5-HT2B receptors in mitral valvulopathy: bone marrow mobilization of endothelial progenitors., Br J Pharmacol 174(22) (2017) 4123-41.

[44] Y. Li, C. Hadden, A. Cooper, A. Ahmed, H. Wu, V.V. Lupashin, P.R. Mayeux, F. Kilic, Sepsis-induced elevation in plasma serotonin facilitates endothelial hyperpermeability, Sci Rep 6 (2016) 22747.

[45] B.A. Ahmed, B.C. Jeffus, S.I.A. Bukhari, J.T. Harney, R. Unal, V.V. Lupashin, P. van der Sluijs, F. Kilic, Serotonin transamidates Rab4 and facilitates its binding to the $C$ terminus of serotonin transporter, J Biol Chem 283(14) (2008) 9388-98.

[46] E. Ayme-Dietrich, R. Lawson, S. Da-Silva, J.P. Mazzucotelli, L. Monassier, Serotonin contribution to cardiac valve degeneration: new insights for novel therapies?, Pharmacological Research (2018).

[47] C. Ullmer, K. Schmuck, H.O. Kalkman, H. Lübbert, Expression of serotonin receptor mRNA in blood vessels, FEBS Lett. 370 (1995) 215-221.

[48] S.W. Watts, S.F. Morrison, R.P. Davis, S.M. Barman, Serotonin and blood pressure regulation, Pharmacol Rev 64(2) (2012) 359-88.

[49] A.E. Linder, W. Ni, T. Szasz, R. Burnett, J. Diaz, T.J. Geddes, D.M. Kuhn, S.W. Watts, A serotonergic system in veins: serotonin transporter-independent uptake, J Pharmacol Exp Ther 325(3) (2008) 714-22.

[50] S.W. Watts, E.S. Darios, B.M. Seitz, J.M. Thompson, 5-HT is a potent relaxant in rat superior mesenteric veins, Pharmacol Res Perspect 3(1) (2015) e00103.

[51] R.K. Kumar, E.S. Darios, R. Burnett, J.M. Thompson, S.W. Watts, Fenfluramine-induced PVAT-dependent contraction depends on norepinephrine and not serotonin, Pharmacological Research (2018).

[52] M.S. Thion, D. Low, A. Silvin, J. Chen, P. Grisel, J. Schulte-Schrepping, R. Blecher, T. Ulas, P. Squarzoni, G. Hoeffel, F. Coulpier, E. Siopi, F.S. David, C. Scholz, F. Shihui, J. Lum, A.A. Amoyo, A. Larbi, M. Poidinger, A. Buttgereit, P.-M. Lledo, M. Greter, J.K.Y. Chan, I. Amit, M. Beyer, J.L. Schultze, A. Schlitzer, S. Pettersson, F. Ginhoux, S. Garel, Microbiome Influences Prenatal and Adult Microglia in a Sex-Specific Manner, Cell 172(3) (2018) 500-516.e16.

[53] K.G. Margolis, M.D. Gershon, M. Bogunovic, Cellular Organization of Neuroimmune Interactions in the Gastrointestinal Tract, Trends Immunol 37(7) (2016) 487-501.

[54] E. Layunta, E. Latorre, R. Forcén, L. Grasa, M.A. Plaza, M. Arias, A.I. Alcalde, J.E. Mesonero, NOD1 downregulates intestinal serotonin transporter and interacts with other pattern recognition receptors, J Cell Physiol 233(5) (2018) 4183-4193.

[55] G. Clarke, S. Grenham, P. Scully, P. Fitzgerald, R.D. Moloney, F. Shanahan, T.G. Dinan, J.F. Cryan, The microbiome-gut-brain axis during early life regulates the hippocampal serotonergic system in a sex-dependent manner, Mol Psychiatry 18(6) (2013) 666-73. 
[56] J.E. Beilharz, N.O. Kaakoush, J. Maniam, M.J. Morris, Cafeteria diet and probiotic therapy: cross talk among memory, neuroplasticity, serotonin receptors and gut microbiota in the rat, Mol Psychiatry 23(2) (2018) 351-361.

[57] V.R. Garbarino, T.L. Gilman, L.C. Daws, G.G. Gould, Extreme enhancement or depletion of serotonin transporter function and serotonin availability in autism spectrum disorder, Pharmacological Research (2018).

[58] N. Israelyan, K.G. Margolis, Serotonin as a link between the gut-brain-microbiome axis in autism spectrum disorders, Pharmacological Research 132 (2018) 1-6.

[59] C. Hadden, T. Fahmi, A. Cooper, A.V. Savenka, V.V. Lupashin, D.J. Roberts, L. Maroteaux, S. Hauguel-de Mouzon, F. Kilic, Serotonin Transporter Protects the Placental Cells Against Apoptosis in Caspase 3-Independent Pathway, J Cell Physiol (2017).

[60] M. Viau, J. Lafond, C. Vaillancourt, Expression of placental serotonin transporter and 5HT 2A receptor in normal and gestational diabetes mellitus pregnancies, Reproductive BioMedicine Online 19(2) (2009) 207-15.

[61] B. Bottalico, I. Larsson, J. Brodszki, E. Hernandez-Andrade, B. Casslén, K. Marsál, S.R. Hansson, Norepinephrine transporter (NET), serotonin transporter (SERT), vesicular monoamine transporter (VMAT2) and organic cation transporters (OCT1, 2 and EMT) in human placenta from pre-eclamptic and normotensive pregnancies, Placenta 25(6) (2004) 518-29.

[62] W.Q. Huang, C.L. Zhang, X.Y. Di, R.Q. Zhang, Studies on the localization of 5hydroxytryptamine and its receptors in human placenta, Placenta 19(8) (1998) 655-61.

[63] G.R. Auda, S.H. Kirk, M.A. Billett, E.E. Billett, Localization of monoamine oxidase mRNA in human placenta, J Histochem Cytochem 46(12) (1998) 1393-400.

[64] H. Kim, Y. Toyofuku, F.C. Lynn, E. Chak, T. Uchida, H. Mizukami, Y. Fujitani, R. Kawamori, T. Miyatsuka, Y. Kosaka, K. Yang, G. Honig, M. Van Der Hart, N. Kishimoto, J. Wang, S. Yagihashi, L.H. Tecott, H. Watada, M.S. German, Serotonin regulates pancreatic beta cell mass during pregnancy, Nat Med 16(7) (2010) 804-8.

[65] C.G. Nebigil, J.-M. Launay, P. Hickel, C. Tournois, L. Maroteaux, 5-Hydroxytryptamine 2B receptor regulates cell-cycle progression: Cross talk with tyrosine kinase pathways, Proc Natl Acad Sci USA 97(6) (2000) 2591-2596.

[66] C.D. Chambers, S. Hernandez-Diaz, L.J. Van Marter, M.M. Werler, C. Louik, K.L. Jones, A.A. Mitchell, Selective serotonin-reuptake inhibitors and risk of persistent pulmonary hypertension of the newborn, N Engl J Med 354(6) (2006) 579-87.

[67] K.F. Huybrechts, B.T. Bateman, K. Palmsten, R.J. Desai, E. Patorno, C. Gopalakrishnan, R. Levin, H. Mogun, S. Hernandez-Diaz, Antidepressant use late in pregnancy and risk of persistent pulmonary hypertension of the newborn, JAMA 313(21) (2015) 2142-51.

[68] A. Wemakor, K. Casson, E. Garne, M. Bakker, M.C. Addor, L. Arriola, M. Gatt, B. Khoshnood, K. Klungsoyr, V. Nelen, M. O'Mahoney, A. Pierini, A. Rissmann, D. Tucker, B. Boyle, L. de Jong-van den Berg, H. Dolk, Selective serotonin reuptake inhibitor antidepressant use in first trimester pregnancy and risk of specific congenital anomalies: a European register-based study, Eur J Epidemiol 30(11) (2015) 1187-98.

[69] M. Balsells, A. Garcia-Patterson, I. Gich, R. Corcoy, Major congenital malformations in women with gestational diabetes mellitus: a systematic review and meta-analysis, Diabetes Metab Res Rev 28(3) (2012) 252-7.

[70] D. Bengel, D.L. Murphy, A.M. Andrews, C.H. Wichems, D. Feltner, A. Heils, R. Mossner, H. Westphal, K.P. Lesch, Altered brain serotonin homeostasis and locomotor insensitivity to 3, 4-methylenedioxymethamphetamine ("Ecstasy") in serotonin transporter-deficient mice, Mol Pharmacol 53(4) (1998) 649-55.

[71] N. Paulmann, M. Grohmann, J.-P. Voigt, B. Bert, J. Vowinckel, M. Bader, M. Skelin, M. Jevsek, H. Fink, M. Rupnik, D.J. Walther, Intracellular serotonin modulates insulin secretion from pancreatic beta-cells by protein serotonylation, PLoS Biol 7(10) (2009) e1000229.

[72] J.A. Armitage, L. Poston, P.D. Taylor, Developmental origins of obesity and the metabolic syndrome: the role of maternal obesity, Front Horm Res 36 (2008) 73-84. 
[73] R.D. Blakely, H.E. Berson, R.T. Fremeau, Jr., M.G. Caron, M.M. Peek, H.K. Prince, C.C. Bradley, Cloning and expression of a functional serotonin transporter from rat brain, Nature 354(6348) (1991) 66-70.

[74] B.J. Hoffman, E. Mezey, M.J. Brownstein, Cloning of a serotonin transporter affected by antidepressants, Science 254(5031) (1991) 579-80.

[75] S. Ramamoorthy, A.L. Bauman, K.R. Moore, H. Han, T. Yang-Feng, A.S. Chang, V. Ganapathy, R.D. Blakely, Antidepressant- and cocaine-sensitive human serotonin transporter: molecular cloning, expression, and chromosomal localization, Proc Natl Acad Sci USA 90(6) (1993) 2542-6.

[76] F. Kilic, G. Rudnick, Oligomerization of serotonin transporter and its functional consequences, Proc Natl Acad Sci USA 97(7) (2000) 3106-11.

[77] D. Ozaslan, S. Wang, B.A. Ahmed, A.M. Kocabas, J.C. McCastlain, A. Bene, F. Kilic, Glycosyl modification facilitates homo- and hetero-oligomerization of the serotonin transporter. A specific role for sialic acid residues, J Biol Chem 278(45) (2003) 439914000.

[78] J.G. Chen, S. Liu-Chen, G. Rudnick, External cysteine residues in the serotonin transporter, Biochemistry 36(6) (1997) 1479-86.

[79] S. Freyaldenhoven, Y. Li, A.M. Kocabas, E. Ziu, S. Ucer, R. Ramanagoudr-Bhojappa, G.P. Miller, F. Kilic, The role of ERp44 in maturation of serotonin transporter protein, J Biol Chem 287(21) (2012) 17801-11.

[80] S.G. Amara, J.L. Arriza, Neurotransmitter transporters: three distinct gene families, Curr Opin Neurobiol 3(3) (1993) 337-44.

[81] Y. Li, C. Hadden, P. Singh, C. Mercado, P. Murphy, N.K. Dajani, C.L. Lowery, D.J. Roberts, L. Maroteaux, F. Kilic, GDM-associated insulin deficiency hinders the dissociation of SERT from ERp44 and down-regulates placental 5-HT uptake, Proc Natl Acad Sci USA 111(52) (2014) E5697-E5705.

[82] Y. Li, A. Cooper, I.N. Odibo, A. Ahmed, P. Murphy, R. Koonce, N.K. Dajani, C.L. Lowery, D.J. Roberts, L. Maroteaux, F. Kilic, Discrepancy in Insulin Regulation between Gestational Diabetes Mellitus (GDM) Platelets and Placenta, J Biol Chem 291(18) (2016) 9657-65. 